\title{
Synthesis of nucleotide-amino acid conjugates designed for photo-CIDNP experiments by a phosphotriester approach
}

\author{
Tatyana V. Abramova*1,2, Olga B. Morozova ${ }^{2,3}$, Vladimir N. Silnikov ${ }^{1}$ \\ and Alexandra V. Yurkovskaya ${ }^{2,3}$
}

\section{Full Research Paper}

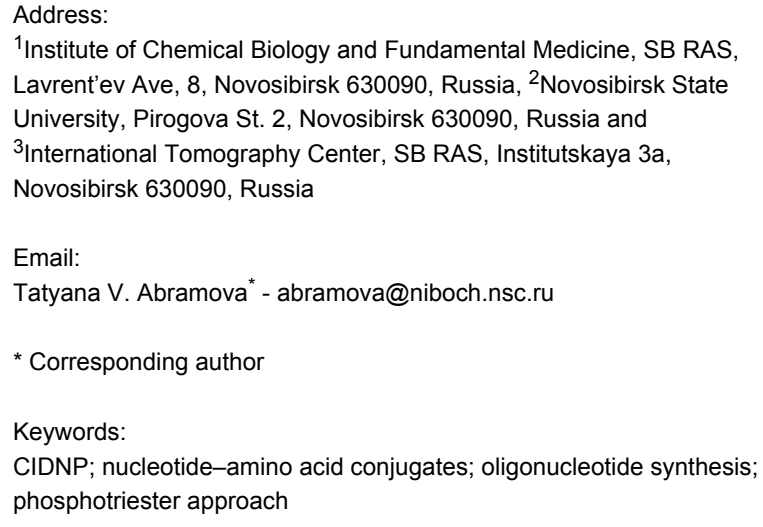

${ }^{1}$ Institute of Chemical Biology and Fundamental Medicine, SB RAS, Lavrent'ev Ave, 8, Novosibirsk 630090, Russia, ${ }^{2}$ Novosibirsk State University, Pirogova St. 2, Novosibirsk 630090, Russia and 3 International Tomography Center, SB RAS, Institutskaya 3a, Novosibirsk 630090, Russia

Email:

Tatyana V. Abramova* - abramova@niboch.nsc.ru

* Corresponding author

Keywords:

CIDNP; nucleotide-amino acid conjugates; oligonucleotide synthesis; phosphotriester approach

Beilstein J. Org. Chem. 2013, 9, 2898-2909. doi:10.3762/bjoc.9.326

Received: 23 September 2013

Accepted: 15 November 2013

Published: 18 December 2013

Associate Editor: D. Spring

(c) 2013 Abramova et al; licensee Beilstein-Institut. License and terms: see end of document.

\begin{abstract}
Conjugates of 2'-deoxyguanosine, L-tryptophan and benzophenone designed to study pathways of fast radical reactions by the photo Chemically Induced Dynamic Nuclear Polarization (photo-CIDNP) method were obtained by the phosphotriester block liquid phase synthesis. The phosphotriester approach to the oligonucleotide synthesis was shown to be a versatile and economic strategy for preparing the required amount of high quality samples of nucleotide-amino acid conjugates.
\end{abstract}

\section{Introduction}

Maintaining the integrity of the genome is of paramount biological importance, since the damage of DNA is considered to cause aging and various degenerative diseases. To prevent the pathological DNA damage, cells evolve the DNA repair machinery, which restores the chemical information encoded in genome. In addition to the enzymatic DNA repair system, a new and quite different repair mechanism, i.e. the non-enzymatic repair, has been discovered. This non-enzymatic system refers to the removal of transient products of the DNA damage like short-lived DNA radicals, with a very high reaction rate by endogenous natural and synthetic compounds, which were extensively studied in chemical systems [1]. This "chemical way" of the DNA repair efficiently competes with the formation of modified sites, which are targets for the enzymatic repair. Since DNA radicals, like all others, are extremely chemically active, they are short-lived, and their concentration is very low to be detected by the conventional electron paramagnetic resonance method. An alternative approach has been developed for the indirect detection of elusive radicals by utilizing nuclear spin hyperpolarization, which occurs in transient radical pairs 
on a microsecond time scale. Nuclear spin hyperpolarization is preserved in diamagnetic products of chemical reactions for several seconds allowing for NMR detection. This approach is based on the phenomenon of Chemically Induced Dynamic Nuclear Polarization (CIDNP).

Nowadays, the time-resolved variant of CIDNP (TR CIDNP) becomes a powerful method in the investigation of vitally important processes with participation of biological macromolecules [2-5]. The possibility of tracking the electron transfer in the reactions of damaged DNA bases by NMR using in situ photoinitiation and the TR CINDP detection opens a new way to profound investigation of mechanisms of DNA repair. Preliminary experiments in this area [6,7] revealed the necessity to study electron transfer processes in detail using a wide number of specially designed model compound conjugates of the amino acid, nucleotide, and dye residues, where key participants (dye, amino acid, and nucleoside) have to be drawn together mimicking the biologically important DNA repair processes.

To fulfill the requirements of the photo-induced TR CIDNP experiments, a synthetic strategy for obtaining the model conjugates should provide a synthetic versatility, easy scaling up, and high purity of the title compounds. Although there is a number of well-developed methods of the automatic solid phase supported synthesis (SPSS) of oligonucleotide-peptide conjugates [8], this strategy does not ensure the availability of the model conjugates for TR NMR photo-CIDNP experiments due to the lack of versatility and difficulties in scaling up the process. As shown in [9], at least $0.01-0.03 \mathrm{mmol}$ of a compound is required for each photo-CIDNP experiment.

In this report, we have designed conjugates consisting of amino acid, nucleotide, and dye residues including linkers of different lengths (Figure 1). Target compounds 1-8 have been synthesized by the phosphotriester block liquid phase synthesis (LPS).

\section{Results and Discussion Design of model compounds}

Our previous studies revealed a great potential of the TR NMR photo-CIDNP technique for the investigation of electron transfer in oxidized peptides and between oxidized DNA nuclear bases and amino acids and small peptides [10,11]. The further development of this work implies the investigation of the electron transfer processes and the detection of elusive radicals in biomolecules using model compounds, where key participants of the reaction (dye, amino acid, and nucleoside) are spatially drawn together mimicking the biologically important DNA repair processes.
Guanosine is the most easily oxidized nucleoside [12] in photoreactions of which pronounced CIDNP effects could be detected [13]. Tryptophan was found as one of the most efficient reducing agents for different protonated forms of oxidized guanosine 5'-monophosphate in a wide $\mathrm{pH}$ range [14]. The 2,2'dipyridyl dye, which is used as a photosensitizer in most of our TR CIDNP experiments, has a disadvantage of a relatively low absorbance at a wavelength of $308 \mathrm{~nm}$ at physiological $\mathrm{pH}$. As an alternative, in our investigations water soluble carboxylic derivatives of benzophenone (namely, 4-carboxy-, 3-carboxyand 3,3',4,4'-tetracarboxybenzophenone) were used as efficient photoinitiating agents for electron transfer from nucleotides and amino acids [15-18].

Based on the above mentioned reasons, we have chosen 4-benzoylbenzoic acid, 2'-deoxyguanosine, and L-tryptophan $[7,9,13-20]$ as the dye, nucleoside, and amino acid building blocks, respectively, to construct conjugates 1-8 (Figure 1) linked in the uniform manner through the phosphate groups.

Conjugates 1 and $\mathbf{6}$ (Figure 1) are binary molecules combining the dye and nucleoside residues or the amino acid and nucleoside residues, respectively. Conjugates $\mathbf{2}$ and $\mathbf{3}$ include all three residues differing in length of the linker between the amino acid and nucleoside residues. Since the amino acid-nucleoside conjugates linked through the phosphamide bond have insufficient stability even at neutral $\mathrm{pH}$ [21], we used L-tryptophanol instead of L-tryptophan in conjugates $\mathbf{3}$ and $\mathbf{5}$ which do not have the linker group between the amino acid and nucleoside residues to avoid this problem. Phosphodiester linkages in conjugates $\mathbf{1 - 8}$ are stable in a wide $\mathrm{pH}$ range.

Conjugates $\mathbf{4}$ and $\mathbf{5}$ containing no guanine nucleobase are control compounds for conjugates $\mathbf{2}$ and $\mathbf{3}$, respectively. Preliminary results revealed a rapid reduction (with the characteristic time of less than $1 \mu \mathrm{s}$ ) of the guanosyl radical by means of electron transfer from the linked tryptophan moiety in conjugate $\mathbf{6}$. This efficient reduction was strictly confirmed by comparing CIDNP kinetics of the photoreaction of conjugate 6 (with 2,2'dipyridyl as photosensitizer) and CIDNP kinetics of the photoreactions of conjugates $\mathbf{7}$ or $\mathbf{8}$ under the same conditions.

\section{Synthesis of model compounds for time resolved photo-CIDNP NMR experiments}

It is easy to notice that conjugates $\mathbf{1}-\mathbf{8}$ are designed as a kind of di- and trimer nucleotide species. So, the key points of its synthesis are the choice of the strategy (SPSS or LPS) and the method of nucleotide condensation. As mentioned in review [22], LPS is the preferable strategy for obtaining semi-preparative and preparative quantities of short oligonucleotides. This strategy was successfully used in the synthesis of native oligo- 

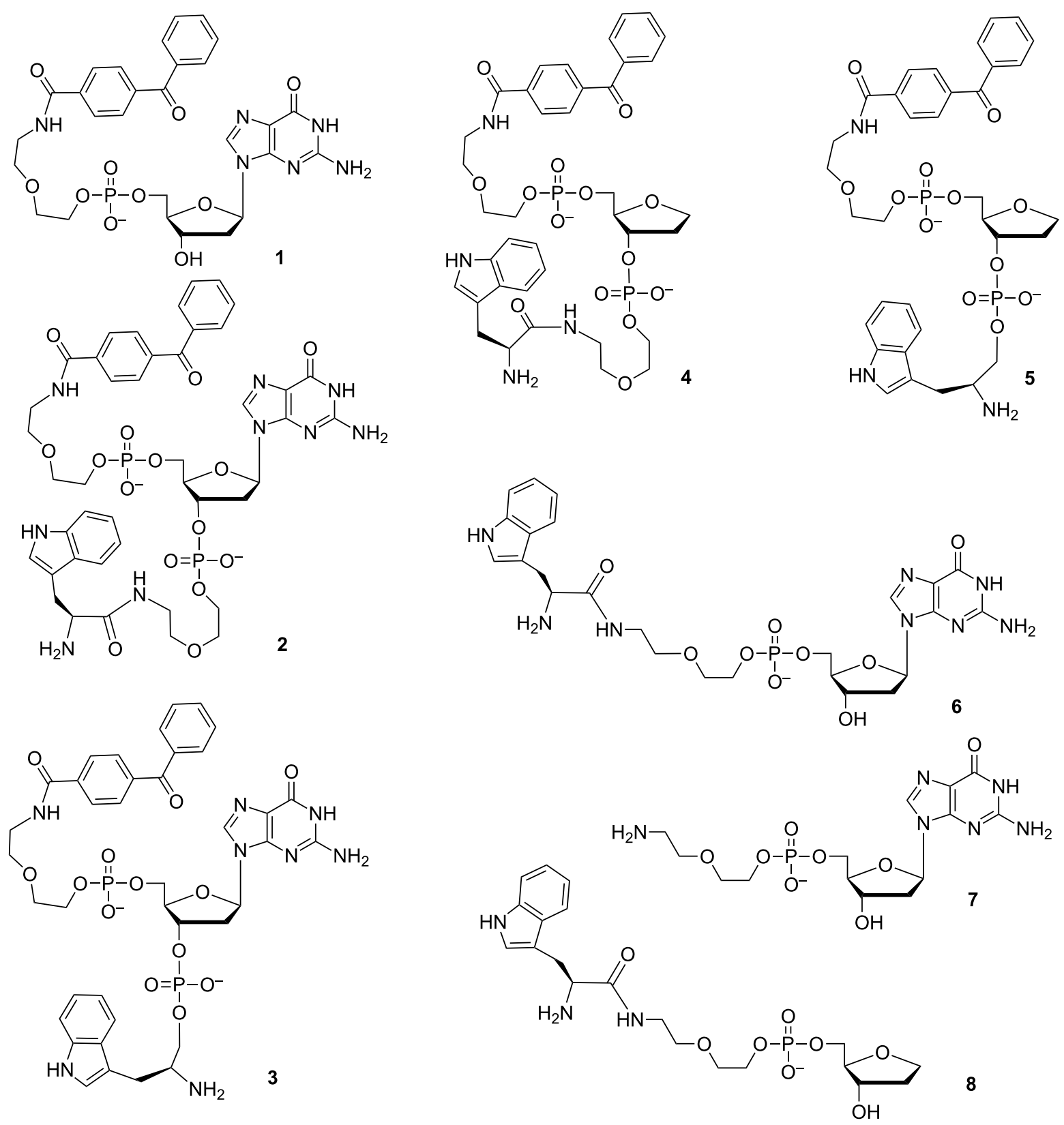

Figure 1: Model compounds for the TR NMR photo-CIDNP experiments: conjugates of 4-benzoylbenzoic acid, 2'-deoxyguanosine, L-tryptophan, and L-tryptophanol.

deoxynucleotides and phosphorothioate hexa-2'-oligodeoxynucleotides by the phosphoramidite method [23,24]. Moreover, LPS was employed for preparing amino acid-nucleotide conjugates [25] and trinucleoside blocks [26] further used in SPSS. The method of nucleotide coupling in LPS presumably depends on the availability of parent compounds and is not limited to the use of more active P(III) nucleotide derivatives.

Taking into account the need for obtaining semi-preparative amounts of conjugates sufficient for TR NMR CIDNP and having in hands the key suitably protected 5'-phosphorylated 2'-deoxyguanosine derivative [27], we used the LPS strategy in combination with the phosphotriester approach for the oligonucleotide synthesis to obtain target conjugates 1-8. The phosphoramidite condensation in LPS usually leads to the lower yields in these reactions due to insufficient stability of active phosphoramidites and the absence of the condensation agent, which dries the solvent and other reagents in the reaction mixture [28]. Functionalized derivatives of commercially available 4-benzoylbenzoic acid, L-tryptophan, and L-tryptophanol, were 
synthesized by the activation of the carboxylic groups of the suitably protected samples to obtain their active esters followed by the introduction of the additional linker moiety and phosphorylation, if necessary (Scheme 1), according to the wellknown procedures [29-31].

The synthetic routes for obtaining conjugates $\mathbf{1}-\mathbf{8}$ are depicted in Scheme 2, Scheme 3, and Scheme 4. 5-O-(4,4'-Dimethoxytrityl)-1,4-anhydro-2-deoxy-D-ribitol (22) was obtained as described in [32]. The synthetic approach outlined in Scheme 2, Scheme 3, and Scheme 4 includes the phosphtriester condensation of specially designed and suitably protected blocks containing dye 9, nucleotide $\mathbf{1 7}$ or its abasic analogues $\mathbf{2 2}$ and 32, and the amino acid (or its reduced derivative) 11, 13, 15, and 16. A series of these blocks and the standard LPS procedures provided a versatile route to obtain semi-preparative amounts (100-200 mg) of the model compounds for the TR CIDNP NMR experiments.
Target conjugates 1-8 were obtained after the deprotection of fully blocked derivatives $18,20,21,25,28,29,31$, and 33 . The pretreatment of these phosphotriester derivatives with TBAF under neutral conditions before aqueous ammonia prevented the cleavage of the linker containing the oxoethyl fragment because of $\beta$-elimination.

It is worthy to notice that the TBAF treatment is essential when the phosphotriester group contains the aromatic residue ( $p$-chlorophenyl in our case), which is much more stable to ammonia than the 2-cyanoethyl group usually used in the phosphoramidite oligodeoxynucleotide synthesis. After the selective cleavage of the aromatic phosphotriester bond by the $\mathrm{F}^{-}$anion, the oxoethyl fragment is quite stable to $\beta$-elimination.

We succeeded in the mild deprotection of derivative $\mathbf{2 0}$ containing the Boc protective group with formic acid but, to our surprise, we failed in this way when the L-tryptophan moiety<smiles>CC(C)(C)Cc1ccc(C(=O)c2ccccc2)cc1C(=O)O</smiles><smiles>CC(C)(C)OC(=O)N[C@H](Cc1c[nH]c2ccccc12)C(=O)NCCOCCO</smiles><smiles>[R]OP(=O)(OC)OCCOCCNC(=O)[C@H](Cc1c[nH]c2ccccc12)NC(=O)OCc1ccccc1</smiles><smiles>NC(CO)Cc1c[nH]c2ccccc12</smiles><smiles>CC#CC(CO)NC(CO)Cc1c[nH]c2ccccc12</smiles><smiles>[R]P(=O)(O[Na])OC[C@H](Cc1c[nH]c2ccccc12)NC=[V]</smiles>

13<smiles>CC#N</smiles><smiles>CC(C)CN[C@@H](Cc1c[nH]c2ccccc12)C(=O)O</smiles><smiles>CCNC(=O)[C@H](Cc1c[nH]c2ccccc12)NC(C)C</smiles>

$\mathrm{HO}$<smiles>[R][R](=O)([O-])OCCOCCNC(=O)[C@H](Cc1c[nH]c2ccccc12)NC(F)F</smiles>

Scheme 1: Synthesis of functionalized derivatives of 4-benzoylbenzoic acid (9), L-tryptophan (11, 16) and L-tryptophanol (13). i) N,N'-Dicyclohexylcarbodiimide (DCC), $\mathrm{N}$-hydroxysuccinimide (NHS), 1,4-dioxane, then 2(2-aminoethoxy)ethanol); ii) 2(2-aminoethoxy)ethanol), triethylamine (TEA), 1,4-dioxane; iii) p-chlorophenyl dichlorophosphate, 1,2,4-triazole, pyridine (Py); iv) ethyl trifluoroacetate, TEA, $\mathrm{MeOH}$. 
<smiles></smiles>

17

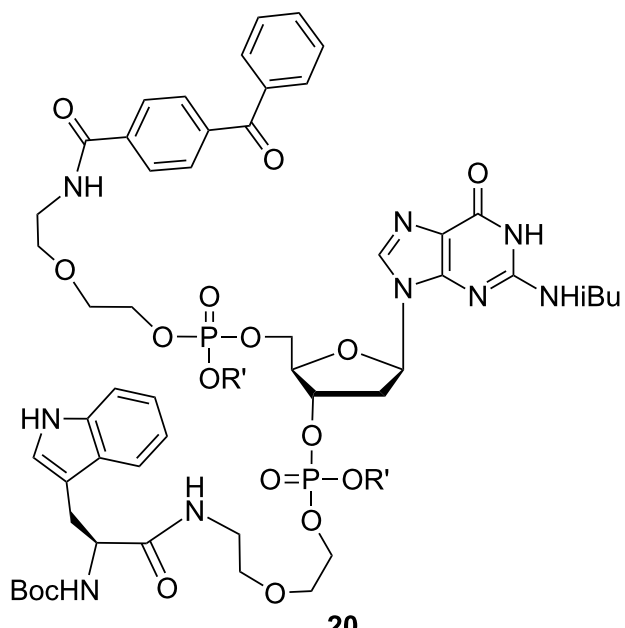<smiles>[V]C1CCCCC1</smiles>

$\mathrm{R}=$ Levulinyl (Lev), $\mathrm{R}^{\prime}=4-\mathrm{CIPh}$

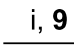

i, 11<smiles>CC(=O)C1=CC=C(C(=O)c2ccccc2)CC1</smiles>

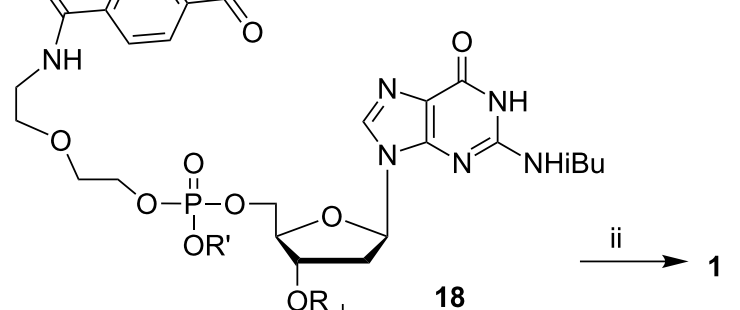

18<smiles></smiles><smiles></smiles>

Scheme 2: Synthesis of conjugates 1-3: i) 2,4,6-triisopropylbenzenesulfonyl chloride (TPSCI), 1-methylimidazole (Melm), Py; ii) tetrabutylammonium fluoride (TBAF) in $\mathrm{Py} / \mathrm{H}_{2} \mathrm{O}$, then $\mathrm{NH}_{3} / \mathrm{H}_{2} \mathrm{O}$; iii) $\mathrm{N}_{2} \mathrm{H}_{4} / \mathrm{H}_{2} \mathrm{O}$ in $\mathrm{Py} / \mathrm{AcOH}$; iv) TBAF in $\mathrm{Py} / \mathrm{H}_{2} \mathrm{O}$, then $\mathrm{NH}_{3} / \mathrm{H}_{2} \mathrm{O}$, then $\mathrm{HC}(\mathrm{O}) \mathrm{OH}$.

was linked to the $5^{\prime}-\mathrm{OH}$ group of $2^{\prime}-\mathrm{dG}$ (conjugate 6). In this case, the deprotection was accompanied by the cleavage of the guanine base at $\mathrm{pH} 1-5$ in aqueous solutions and under the action of a TFA/ $\mathrm{CH}_{2} \mathrm{Cl}_{2}$ mixture. So, we replaced Boc by the trifluoroacetyl protective group and synthesized the additional building block 15 to obtain conjugate 6 (Scheme 4).

Keeping in mind the possibility of a further modification of fully protected derivative 31, we chose the acid labile MMTr protective group for the linker to obtain conjugate 7 because such protection is orthogonal to the protective groups of nucleotide block 17.

After the deprotection, target conjugates 1-8 were purified by the anion exchange and reversed phase chromatography (RPC) at a medium pressure, which provides the high purity of the final products and easy scaling up in laboratory conditions. The homogeneity and structures of all key intermediates and final 


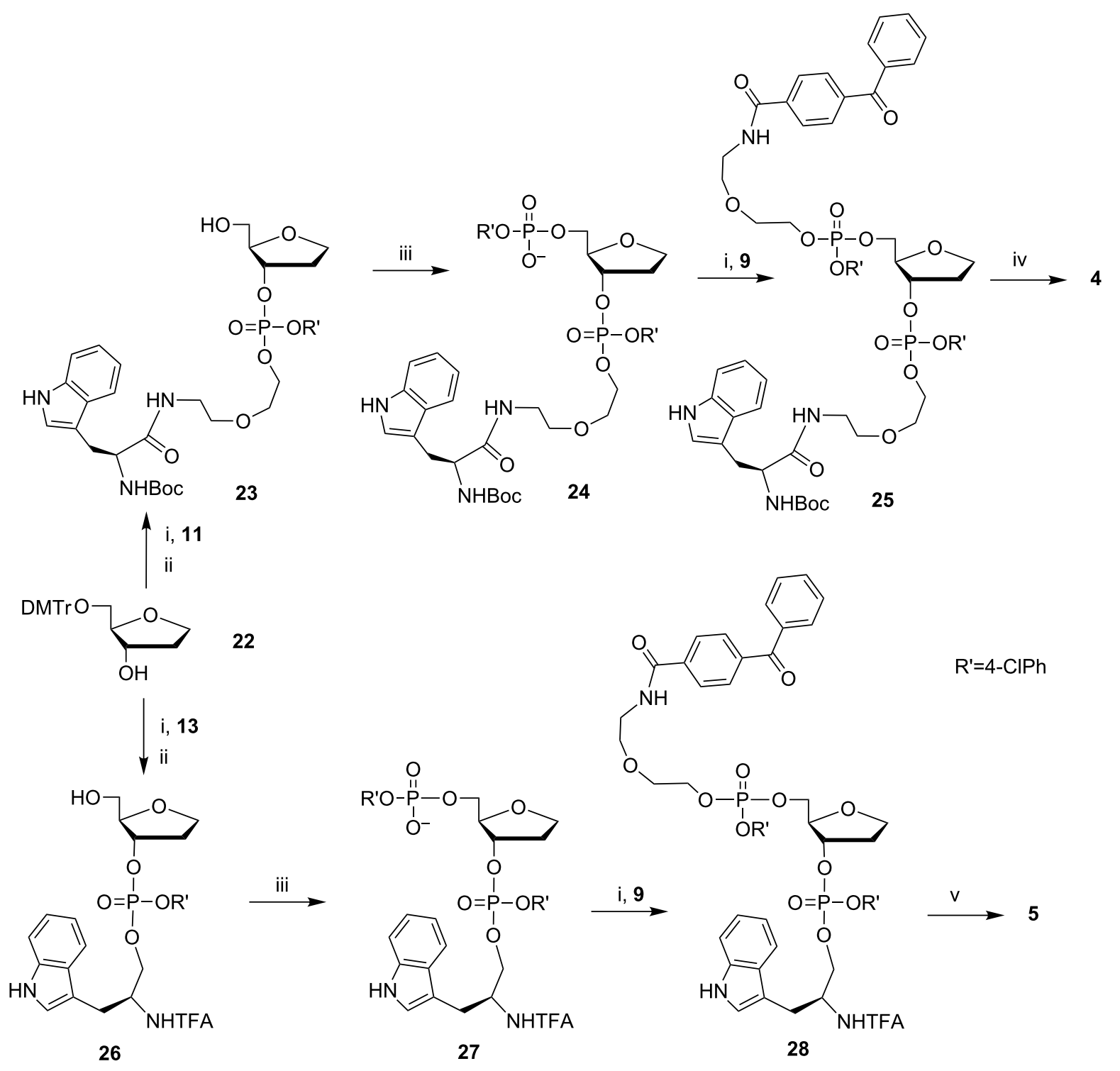

Scheme 3: Synthesis of conjugates 4 and 5: i) TPSCl, Melm, Py; ii) AcOH/ $\mathrm{H}_{2} \mathrm{O}$; iii) p-chlorophenyl dichlorophosphate, 1,2,4-triazole, Py; iv) TBAF in $\mathrm{Py} / \mathrm{H}_{2} \mathrm{O}$, then $\mathrm{HC}(\mathrm{O}) \mathrm{OH}$; v) TBAF in $\mathrm{Py} / \mathrm{H}_{2} \mathrm{O}$, then $\mathrm{NH}_{3} / \mathrm{H}_{2} \mathrm{O}$.

compounds were confirmed by thin-layer chromatography (TLC), RPC, NMR and mass-spectrometry analysis.

\section{Conclusion}

We designed and synthesized a number of model conjugates to study the role of electron transfer and the elusive radical formation in biologically significant processes. By any standards, the use of the hyperpolarization approach is extraordinary to elucidate the interactions between hidden transient intermediates of nucleosides and amino acids in conjugates, which mimic biologically relevant processes. The liquid phase synthesis (LPS) in combination with the phosphotriester approach appeared to meet the requirements for the in situ NMR detection of the radical reactions with microsecond time resolution by Chemically Induced Dynamic Nuclear Polarization (CIDNP). Based on our fruitful experience in the CIDNP investigation of conjugates $\mathbf{1}, \mathbf{6}, \mathbf{7}$, and $\mathbf{8}$ (will be published soon separately), we are confident that the expansion of this study to other analogous model systems is worth doing for elucidation of complex chemistry, which is developed in nature for maintaining the integrity of the genome encoded in DNA

\section{Experimental}

We used L-tryptophan (Fisher Scientific, USA), Boc- $N H$-Ltryptophan pentachlorophenyl ester (Reanal, Hungary), 2-(2aminoethoxy)ethanol (Acros Organics, USA). Other reagents 
<smiles>[R]OC1CC2OC1(COP([R2])(=O)OC)CC2n1cnc2c(=O)[nH]c(NCCC)nc21</smiles>

17

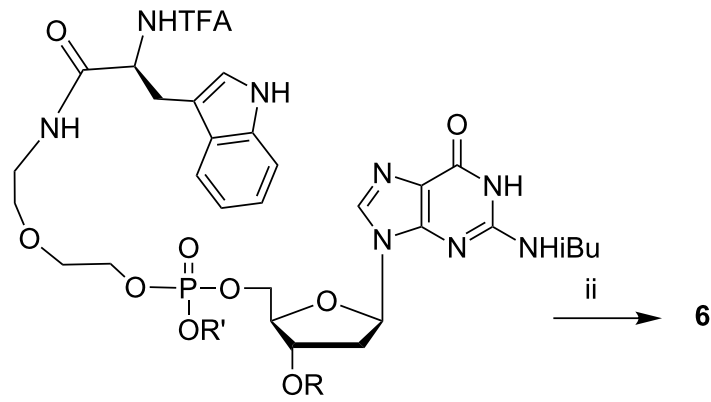

29

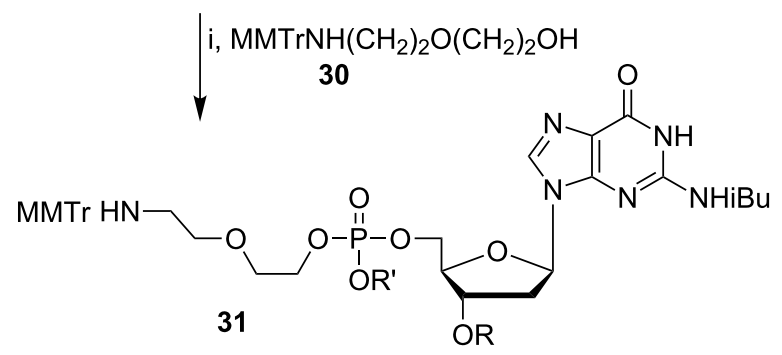

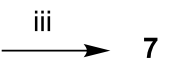<smiles>O=[W]OCC1OCCC1O</smiles><smiles>C1CCC(C2CCCCC2)CC1</smiles><smiles>COC1CCOC(CO)C1</smiles><smiles>[R]P(=O)([O-])OCCOCCNC(=O)[C@H](Cc1c[nH]c2ccccc12)NC(F)F</smiles>

16
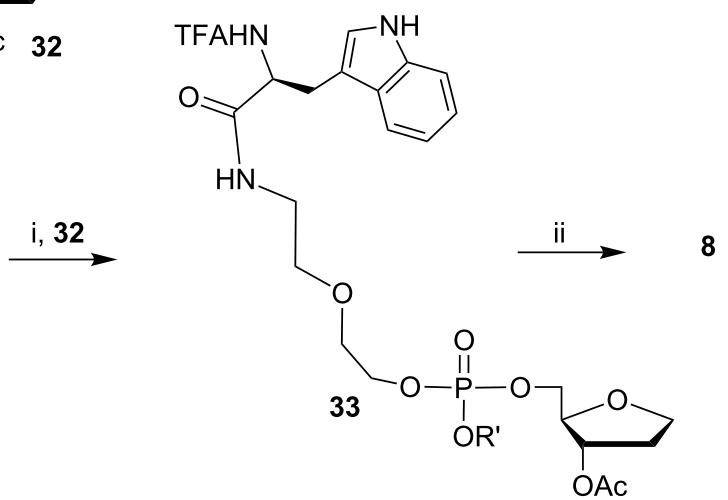

Scheme 4: Synthesis of conjugates 6-8. i) TPSCl, Melm, Py; ii) TBAF in $\mathrm{Py} / \mathrm{H}_{2} \mathrm{O}$, then $\mathrm{NH}_{3} / \mathrm{H}_{2} \mathrm{O}$; iii) $T B A F$ in $\mathrm{Py} / \mathrm{H}_{2} \mathrm{O}$, then $\mathrm{NH}_{3} / \mathrm{H}_{2} \mathrm{O}$, then $\mathrm{AcOH} / \mathrm{H}_{2} \mathrm{O}$; iv) $\mathrm{Ac}{ }_{2} \mathrm{O}$, Py, then $\mathrm{AcOH} / \mathrm{H}_{2} \mathrm{O}$.

were from Sigma-Aldrich, Inc. (USA). Organic solvents were dried and purified by standard procedures. The reaction mixtures were analyzed on a Milichrom A02 analytical chromatograph system (Econova, Russia) using a ProntoSIL 125 C18 column $(2 \times 75 \mathrm{~mm})$ and gradient of buffer B $(0.1 \mathrm{M}$ TEA-AcOH, $\mathrm{pH} 7.0,80 \%$ acetonitrile $)$ in buffer $\mathrm{A}(0.1 \mathrm{M}$ TEA-AcOH, pH 7.0, water) with UV detection at 250, 260, 280 , and $300 \mathrm{~nm}$. TLC was carried out on Kieselgel $60 \mathrm{~F}_{254}$ plates (Merck, Germany) in the proper solvent systems (see below) and spots were visualized by UV irradiation, ninhydrin (for amine groups) or cysteine/aqueous sulfuric acid (for nucleosides and tryptophan) solution. Evaporations were performed under reduced pressure at $40{ }^{\circ} \mathrm{C}$. The preparative silica gel column chromatography was performed using
Kieselgel 55-100 $\mu \mathrm{m}$ (Merck, Germany); RPC, a Porasil C 18 (55-105 $\mu \mathrm{m}, 125 \mathrm{~A})$ (Waters, USA); and anion exchange chromatography, DEAE Sephadex A-25 (Pharmacia, Sweden). Eluent composition is given in $\mathrm{v} / \mathrm{v}$ per cent. NMR spectra were acquired on Bruker AM-400 and AV-300 instruments (Bruker, Germany) in appropriate deuterated solvents at $30^{\circ} \mathrm{C}$. Chemical shifts $(\delta)$ are reported in ppm relative to the TMS signal. In the case of ${ }^{31} \mathrm{P}$ and ${ }^{19} \mathrm{~F}$, external standards of $85 \% \mathrm{H}_{3} \mathrm{PO}_{4}$ and $\mathrm{C}_{6} \mathrm{~F}_{6}$, respectively, were used. Coupling constants $J$ are reported in Hertz. Mass spectra were registered in The Center of Cooperative Use "Proteomics", Russian Academy of Sciences, on an Autoflex III mass spectrometer (Bruker Daltonics, Inc.) using 2,5-dihydroxybenzoic acid as a matrix (MALDI-TOF) in positive or negative mode. 
Compound 22 was synthesized according to the published method [32]. Trifluoroacetamido- $N H$-tryptophan was obtained as described in [33]. The syntheses of compounds $9, \mathbf{1 0}, \mathbf{1 2}, \mathbf{1 5}$, 30, and 32 were carried out according to the well-known methods [29,30] (see Supporting Information File 1 for details).

\section{Synthesis of 2-N-isobutyryl-3'-O-levulinyl-2'- deoxyguanosine 5'-O-(p-chlorophenyl)phos- phate (17)}

The synthetic scheme and physicochemical data of intermediate compounds see Supporting Information File 1.

2'-Deoxyguanosine 5'-monophosphate (5 g, $12.5 \mathrm{mmol}$, disodium salt, $0.1 \mathrm{M}$ solution in $20 \%$ aqueous $\mathrm{EtOH}$ ) was converted into $\mathrm{NH}_{4}{ }^{+}$form on a DEAE A-25 column $(200 \mathrm{~mL})$ by elution with $1 \mathrm{M} \mathrm{NH}_{4} \mathrm{HCO}_{3}$. The desired fractions were evaporated; traces of buffer were removed by coevaporation with water. The last portion of water was added along with TEA $(14 \mathrm{~mL}, 100 \mathrm{mmol})$. The residue was coevaporated with acetonitrile $(3 \times 25 \mathrm{~mL})$ and Py $(2 \times 20 \mathrm{~mL})$ and dissolved in Py $(60 \mathrm{~mL})$. Chlorotrimethylsilane $(8.2 \mathrm{~mL}, 6 \mathrm{mmol})$ was added to the solution under vigorous stirring for $30 \mathrm{~min}$, followed by the addition of isobutyryl chloride $(2.7 \mathrm{~mL}, 26 \mathrm{mmol})$. After stirring the mixture overnight, it was cooled in an ice bath followed by the addition of water $(7 \mathrm{~mL})$ and then (after $10 \mathrm{~min}$ ) $25 \%$ aqueous ammonia. The cooling bath was removed and the reaction mixture was stirred for $1 \mathrm{~h}$ at room temperature. After evaporation, the residue was dissolved in water, and the target product was purified by RPC in a linear gradient of EtOH in water $(0-20 \%)$. The appropriate fractions were pooled and evaporated. After drying, 2- $N$-isobutyryl-2'-deoxyguanosine 5 '-monophosphate $(5.40 \mathrm{~g}, 12.0 \mathrm{mmol})$ was obtained as a cream-coloured powder. Before the next step (protection of the 3 '-OH group by the levulinyl residue), the nucleotide with the protected nucleobase was converted to the TEA salt by adding TEA ( $5 \mathrm{~mL}, 35 \mathrm{mmol}$ ) to its solution in $50 \%$ aqueous Py $(50 \mathrm{~mL})$, evaporation of resulting mixture and drying the oil residue by coevaporation with acetonitrile $(2 \times 25 \mathrm{~mL})$ and Py $(2 \times 20 \mathrm{~mL})$.

Levulinic acid (11.6 g, $100 \mathrm{mmol})$ and DCC (10.3 g, $50 \mathrm{mmol})$ was dissolved in diethyl ether $(150 \mathrm{~mL})$, and the mixture was stirred for $3 \mathrm{~h}$. After filtration, the diethyl ether was removed from the filtrate by evaporation; the residue was dissolved in Py $(50 \mathrm{~mL})$, and the solution was transferred to the flask containing 2- $\mathrm{N}$-isobutyryl-2'-deoxyguanosine 5'-monophosphate (TEA salt) and MeIm (4 mL, $50 \mathrm{mmol})$. The reaction mixture was left for $3 \mathrm{~h}$, followed by adding water $(50 \mathrm{~mL})$ and stirring the mixture for $3 \mathrm{~h}$. The reaction mixture was then evaporated several times with water to remove traces of Py. The target product was purified by RPC in a linear gradient of EtOH in water $(0-40 \%)$.
The appropriate fractions were pooled and evaporated. After drying, 2- $N$-isobutyry-3'-O-levulinyl-2'-deoxyguanosine 5 '-monophosphate $(6.0 \mathrm{~g}, 10.0 \mathrm{mmol})$ was obtained as a glasslike residue.

2- $\mathrm{N}$-Isobutyryl-3'-O-levulinyl-2'-deoxyguanosine 5'-monophosphate $(6.0 \mathrm{~g}, 10.0 \mathrm{mmol})$ was dissolved in $\mathrm{CH}_{2} \mathrm{Cl}_{2}$ (45 mL). Triphenylphosphine ( $8.0 \mathrm{~g}, 30 \mathrm{mmol}), 2,2^{\prime}-$ dithiodipyridine $(6.6 \mathrm{~g}, 30 \mathrm{mmol})$, and MeIm $(4.8 \mathrm{~mL}$, $60 \mathrm{mmol}$ ) were added to the nucleotide solution. After $30 \mathrm{~min}$ of incubation, the solution of $p$-chlorophenol $(6.4 \mathrm{~g}, 50 \mathrm{mmol})$ and TEA $(21 \mathrm{~mL}, 150 \mathrm{mmol})$ in $\mathrm{CH}_{2} \mathrm{Cl}_{2}(30 \mathrm{~mL})$ was added, and the reaction mixture was stirred for $3 \mathrm{~h} . \mathrm{CH}_{2} \mathrm{Cl}_{2}$ was then evaporated, the residue was dissolved in $50 \%$ aqueous $\mathrm{Py}$ $(100 \mathrm{~mL})$, The solution was washed with diethyl ether $(2 \times$ $100 \mathrm{~mL}$ ), and the product was extracted with a $\mathrm{CH}_{2} \mathrm{Cl}_{2} / 1$ butanol mixture $(7 / 3,2 \times 75 \mathrm{~mL})$. The organic layer was evaporated, the residue was dissolved in a minimal volume of $30 \%$ aqueous EtOH and loaded on the top of the column containing reversed phase resin equilibrated with water. The target product was purified by RPC in a linear gradient of acetonitrile in water $(0-50 \%)$. The appropriate fractions were pooled and evaporated. After drying, 2- $\mathrm{N}$-isobutyryl-3'-O-levulinyl-2'deoxyguanosine 5'-O-(p-chlorophenyl)phosphate (1/2 TEA salt, $5.5 \mathrm{~g}, 7.5 \mathrm{mmol}, 60 \%$ yield relative to initial 2'-deoxyguanosine 5'-monophosphate) was obtained as a dry glass-like yellowish hydroscopic powder. $R_{\mathrm{f}}$ : $0.63\left(\mathrm{iPrOH} / \mathrm{H}_{2} \mathrm{O} 4 / 1\right)$; ${ }^{31} \mathrm{P}$ NMR $\left(\mathrm{CD}_{3} \mathrm{OD}\right) 4.75 ;{ }^{1} \mathrm{H} \mathrm{NMR}\left(\mathrm{CD}_{3} \mathrm{OD}\right) 8.68$ (br.s, $1 \mathrm{H}$, $\mathrm{N} H$-Gua), 8.14 (s, 1H, H8-Gua), 7.16-7.07 (m, 4H, H-pClPh), $6.31\left(\mathrm{dd}, J=5.3,9.3, H 1^{\prime}\right), 5.48$ (m, 1H, H3'), 4.35-4.24 (m, $3 \mathrm{H}, \mathrm{H}-5$ ', 5 ' ', 4 '), 3.22 (q, $J=7.3,3 \mathrm{H}, \mathrm{CH}_{2}$-TEA), 2.89-2.83 $\left(\mathrm{m}, 3 \mathrm{H}, \mathrm{H} 2^{\prime}, \mathrm{O}(\mathrm{O}) \mathrm{CCH}_{2}\right), 2.78$ (sep, $\mathrm{J}=6.8,1 \mathrm{H}, \mathrm{CH}\left(\mathrm{CH}_{3}\right)_{2}$, 2.64-2.57 (m, 2H, $\mathrm{CH}_{2} \mathrm{C}(\mathrm{O}) \mathrm{CH}_{3}$,), 2.47-2.38 (m, $1 \mathrm{H}, \mathrm{H}_{2}{ }^{\prime}$ '), $2.20\left(\mathrm{~s}, 3 \mathrm{H}, \mathrm{C}(\mathrm{O}) \mathrm{CH}_{3}\right), 1.32\left(\mathrm{t}, 6 \mathrm{H}, \mathrm{CH}_{3}\right.$-TEA), 1.21 (d, $\left.J=6.8,3 \mathrm{H}, \mathrm{CH}\left(\mathrm{CH}_{3}\right)_{2}\right), 1.19\left(\mathrm{~d}, J=6.8,3 \mathrm{H}, \mathrm{CH}\left(\mathrm{CH}_{3}\right)_{2}\right)$; MALDI-TOFMS $(\mathrm{m} / \mathrm{z})$ : $[\mathrm{M}+\mathrm{H}]^{+}$calcd for $\mathrm{C}_{25} \mathrm{H}_{30} \mathrm{ClN}_{5} \mathrm{O}_{10} \mathrm{P}$, 626.14; found, 626.05; $[\mathrm{M}+\mathrm{Na}]^{+}$calcd for $\mathrm{C}_{25} \mathrm{H}_{29} \mathrm{ClN}_{5} \mathrm{NaO}_{10} \mathrm{P}, 648.12$; found, 648.04 .

\section{General phosphorylation procedure}

Compound 10, 12, 15, 23, or $26(0.2 \mathrm{mmol})$ and 1,2,4-triazole $(0.08 \mathrm{~g}, 1.2 \mathrm{mmol})$ were coevaporated with Py $(3 \times 1 \mathrm{~mL})$, dissolved in Py $(1 \mathrm{~mL})$, and 4-chlorophenyl dichlorophosphate $(0.24 \mathrm{mmol}, 0.04 \mathrm{~mL})$ was added to the solution under vigorous stirring. After $30 \mathrm{~min}$, the reaction was stopped by the addition of several drops of aqueous $5 \% \mathrm{NaHCO}_{3}$, and the reaction mixture was evaporated with water to remove Py. The residue was suspended in water, and the target product (compound 11, 13, $\mathbf{1 6}, \mathbf{2 4}$, or 27) was purified by RPC in a linear gradient of acetonitrile in water $(0-50 \%)$. The appropriate fractions were pooled and evaporated. Typical yield was $90 \%$ (1/2 Py salt). See 
Supporting Information File 1 for physicochemical characteristics of compounds 11, 13, 16, 24 and 27.

\section{Phosphotriester condensation}

The coupling reactions afforded fully blocked derivatives $\mathbf{1 8}$, 20, 21, 25, 28, 29, 31, and 33 were performed according to [34]. After silica gel chromatography, the appropriate fractions were evaporated, and the residue of the fully protected conjugate was subjected to deprotection. Target conjugates 1-8 were purified and characterized (see below). The DMTr protective group was removed after the coupling reaction (compounds $\mathbf{2 3}$ and 26) according to [28]. The selective removal of the Lev protective group from compound $\mathbf{1 8}$ was performed according to [35]. See Supporting Information File 1 for physicochemical data of compounds 19,23 , and 26 .

\section{Deprotection of fully blocked derivatives and purification of conjugates 1-8}

Compounds 18, 20, 21, 25, 28, 29, 31, or 33 after purification by silica gel chromatography (see above) were mixed with $0.33 \mathrm{M}$ solution of TBAF in $50 \%$ aqueous Py $(\mathrm{pH} 7.0,1.0 \mathrm{~mL}$ per $0.05 \mathrm{~g}$ of the fully protected derivative) and stirred at $40{ }^{\circ} \mathrm{C}$ overnight. The reaction mixtures were then evaporated several times with water to remove Py. The subsequent purification of products by anion exchange chromatography and RPC depended on the combination of the protective groups and a number of negatively and positively charged residues.

\section{Conjugate 1}

Partly deprotected by the TBAF treatment conjugate $\mathbf{1 8}$ was treated with concentrated (25\%) aqueous ammonia for $48 \mathrm{~h}$ at room temperature under stirring, and the mixture was evaporated. The residue was dissolved in $40 \%$ aqueous $\mathrm{EtOH}(10 \mathrm{~mL}$ per $0.05 \mathrm{~g}$ of the fully protected derivative), and the solution was applied to a column with DEAE Sephadex A-25 in 40\% aqueous EtOH. Elution was performed with a linear gradient of $\mathrm{NH}_{4} \mathrm{HCO}_{3}(0-0.5 \mathrm{M})$ in $40 \%$ aqueous EtOH. The appropriate fractions were pooled and evaporated. Target product $\mathbf{1}$ was then purified by RPC in a linear gradient of acetonitrile in water $(0-20 \%)$ in the presence of $0.05 \mathrm{M} \mathrm{NH}_{4} \mathrm{HCO}_{3}$. After drying, $0.120 \mathrm{~g}$ of conjugate $1(0.19 \mathrm{mmol}, 37 \%$ calcd to 9 taken into the coupling reaction) was obtained. $R_{\mathrm{f}}: 0.53\left(\mathrm{iPrOH} / \mathrm{H}_{2} \mathrm{O}, 4 / 1\right)$; ${ }^{31} \mathrm{P}$ NMR $\left(\mathrm{D}_{2} \mathrm{O}\right) 1.05(\mathrm{~s}) ;{ }^{1} \mathrm{H}$ NMR $\left(\mathrm{D}_{2} \mathrm{O}\right) 8.01(\mathrm{~s}, 1 \mathrm{H}$, $H 8$-Gua), 7.91 (dt, $J=8.2,1.6,2 \mathrm{H}, H$-Ar), 7.79 (dt, $J=8.2$, 1.6, 2H, $H$-Ar), 7.76, (dt, $J=7.4,1.5,2 \mathrm{H}, H$-Ar), 7.71 (tt, $J=7.5,1.2,1 \mathrm{H}, H$-Ar), 7.56 (tt, $J=7.4,1.5,2 \mathrm{H}, H$-Ar), 6.20 (t, $\left.J=7.1,1 \mathrm{H}, H 1^{\prime}\right), 4.65-4.59\left(\mathrm{~m}, 1 \mathrm{H}, H 4^{\prime}\right), 4.08-4.02(\mathrm{~m}$, $\left.1 \mathrm{H}, H 3{ }^{\prime}\right), 4.05-4.00\left(\mathrm{~m}, 2 \mathrm{H}, \mathrm{OCH}_{2} \mathrm{CH}_{2} \mathrm{OP}\right), 3.98-3.92(\mathrm{~m}, 2 \mathrm{H}$, $\mathrm{OCH}_{2} \mathrm{CH}_{2} \mathrm{OP}$ ), 3.70 (t, $\mathrm{J}=5.3,2 \mathrm{H}, \mathrm{NHCH}_{2} \mathrm{CH}_{2} \mathrm{O}$ ), 3.68-3.64 (m, 2H, H5 '5 '), 3.59 (t, $\mathrm{J}=5.3,2 \mathrm{H}, \mathrm{NHCH}_{2} \mathrm{CH}_{2} \mathrm{O}$ ), 2.54-2.43 (m, 1H, H2'), 2.34-2.24 (m, 1H, H2'); MALDI-TOFMS ( $\mathrm{m} / \mathrm{z})$ :
$[\mathrm{M}+\mathrm{H}]^{+}$calcd for $\mathrm{C}_{28} \mathrm{H}_{32} \mathrm{~N}_{6} \mathrm{O}_{10} \mathrm{P}, 643.19$; found, 643.19; $[\mathrm{M}+\mathrm{Na}]^{+}$calcd for $\mathrm{C}_{28} \mathrm{H}_{31} \mathrm{~N}_{6} \mathrm{NaO}_{10} \mathrm{P}, 665.17$; found, 665.21; $[\mathrm{M}+\mathrm{K}]^{+}$calcd for $\mathrm{C}_{28} \mathrm{H}_{31} \mathrm{KN}_{6} \mathrm{O}_{10} \mathrm{P}, 681.15$; found, 681.20; $[\mathrm{M}-\mathrm{H}]^{-}$calcd for $\mathrm{C}_{28} \mathrm{H}_{30} \mathrm{~N}_{6} \mathrm{O}_{10} \mathrm{P}, 641.18$; found, 641.62.

\section{Conjugate 2}

Partly deprotected by TBAF treatment conjugate $\mathbf{2 0}$ was dissolved in a minimal amount of $30 \%$ aqueous $\mathrm{EtOH}$ and placed on the top of the column containing reversed phase resin equilibrated with water. Elution was performed with a linear gradient of EtOH in water (0-50\%) in the presence of $0.05 \mathrm{M}$ $\mathrm{NH}_{4} \mathrm{HCO}_{3}$. The appropriate fractions were pooled and evaporated. The residue was treated with concentrated (25\%) aqueous ammonia for $48 \mathrm{~h}$ at room temperature under stirring, and the mixture was evaporated. The residue was dissolved in formic acid $(1.5 \mathrm{~mL})$. After $3 \mathrm{~h}$, crude conjugate 2 was precipitated by diethyl ether $(15 \mathrm{~mL})$, the tube was frozen at $-20{ }^{\circ} \mathrm{C}$, and the precipitate was collected by centrifugation. Target product 2 was purified by RPC in a linear gradient of acetonitrile in water $(0-30 \%)$ in the presence of $0.05 \mathrm{M} \mathrm{NH}_{4} \mathrm{HCO}_{3}$. After drying, $0.06 \mathrm{~g}$ of conjugate $2(0.06 \mathrm{mmol}, 15 \%$ calcd to 19 taken into the coupling reaction) was obtained. $R_{\mathrm{f}}: 0.43\left(\mathrm{iPrOH} / \mathrm{H}_{2} \mathrm{O}, 4 / 1\right)$; ${ }^{31} \mathrm{P}$ NMR $\left(\mathrm{D}_{2} \mathrm{O}\right) 0.82$ (s, 1P), $-0.10(\mathrm{~s}, 1 \mathrm{P}) ;{ }^{1} \mathrm{H}$ NMR $\left(\mathrm{D}_{2} \mathrm{O}\right)$ 7.75 (s, 1H, H8-Gua), 7.71-7.57 (m, 7H, H-Ar), 7.51 (t, $J=7.7$, 2H, $H$-Ar), 7.40 (d, $J=7.8,1 \mathrm{H}, H$-Trp), 7.29 (d, $J=7.8,1 \mathrm{H}$, $H$-Trp), 7.12 (s, 1H, H-Trp), 7.04 (t, $J=7.8, H$-Trp), 6.95 (t, $J=7.8, H$-Trp), 5.84 (t, $J=7.0,1 \mathrm{H}, H 1$ '), 4.91-4.83 (m, 1H, $H 4$ '), 4.29-4.22 (m, 1H, H3'), $4.10(\mathrm{t}, J=6.5,1 \mathrm{H}$, $\left.\mathrm{CH}\left(\mathrm{NH}_{2}\right) \mathrm{CH}_{2}\right), 4.00-3.87\left(\mathrm{~m}, 8 \mathrm{H}, \mathrm{OCH}_{2} \mathrm{CH}_{2} \mathrm{OP}\right), 3.87-3.44$ $\left(\mathrm{m}, 10 \mathrm{H}, \mathrm{NHCH}_{2} \mathrm{CH}_{2} \mathrm{O}, \mathrm{H}^{\prime}{ }^{\prime}\right.$ ”) $), 3.42-3.32(\mathrm{~m}, 1 \mathrm{H}$, $\left.\mathrm{CH}\left(\mathrm{NH}_{2}\right) \mathrm{CH}_{2}\right), 3.24-3.12\left(\mathrm{~m}, 1 \mathrm{H}, \mathrm{CH}\left(\mathrm{NH}_{2}\right) \mathrm{CH}_{2}\right), 2.56-2.37$ (m, 2H, H2 'H2"); MALDI-TOFMS $(\mathrm{m} / \mathrm{z})$ : $[\mathrm{M}+\mathrm{H}]^{+}$calcd for $\mathrm{C}_{43} \mathrm{H}_{52} \mathrm{~N}_{9} \mathrm{O}_{15} \mathrm{P}_{2}$, 996.30; found, 996.20; $[\mathrm{M}+\mathrm{Na}]^{+}$calcd for $\mathrm{C}_{43} \mathrm{H}_{51} \mathrm{~N}_{9} \mathrm{NaO}_{15} \mathrm{P}_{2}, 1018.29$; found, 1018.19.

\section{Conjugate 3}

Partly deprotected by TBAF treatment conjugate 21 was subjected to RPC as described for partly deprotected by TBAF conjugate 20. The residue was then treated with concentrated (25\%) aqueous ammonia for $48 \mathrm{~h}$ at room temperature under stirring. After evaporation, target product 3 was purified by RPC as described for conjugate 2. After drying, $0.03 \mathrm{~g}$ of conjugate $3(0.033 \mathrm{mmol}, 33 \%$ calcd to $\mathbf{1 9}$ taken into the coupling reaction) was obtained. $R_{\mathrm{f}}: 0.40\left(\mathrm{iPrOH} / \mathrm{H}_{2} \mathrm{O}, 4 / 1\right) ;{ }^{31} \mathrm{P} \mathrm{NMR}$ $\left(\mathrm{D}_{2} \mathrm{O}\right) 0.76(\mathrm{~s}, 1 \mathrm{P}),-0.66(\mathrm{~s}, 1 \mathrm{P}) ;{ }^{1} \mathrm{H} \mathrm{NMR}\left(\mathrm{D}_{2} \mathrm{O}\right) 7.76(\mathrm{~s}, 1 \mathrm{H}$, $H 8$-Gua), 7.66-7.38 (m, 10H, $H$-Ar, $H$-Trp), 7.19 (s, 1H, $H$-Trp), 7.18-7.10 (m, 1H, H-Trp), 6.96-6.85 (m, 2H, H-Trp), $5.71\left(\mathrm{dd}, J=6.1,8.1,1 \mathrm{H}, H 1^{\prime}\right), 4.79-4.68$ (m, 1H, H4'), $4.17-4.10\left(\mathrm{~m}, 1 \mathrm{H}, H 3\right.$ '), 4.08-4.01 (m, $\left.1 \mathrm{H}, \mathrm{CH}_{2} \mathrm{CH}\left(\mathrm{NH}_{2}\right) \mathrm{CH}_{2}\right)$, 4.00-3.86 (m, 4H, OCH $\left.\mathrm{CH}_{2} \mathrm{OP}\right), 3.86-3.73(\mathrm{~m}, 2 \mathrm{H}$, $\left.\mathrm{CH}_{2} \mathrm{CH}\left(\mathrm{NH}_{2}\right) \mathrm{CH}_{2}, \mathrm{CH}_{2} \mathrm{CH}\left(\mathrm{NH}_{2}\right) \mathrm{CH}_{2}\right), 3.72-3.59(\mathrm{~m}, 4 \mathrm{H}$, 
$\mathrm{NHCH}_{2} \mathrm{CH}_{2} \mathrm{O}$ ), 3.58-3.48 (m, 2H, H5 '5 '), 3.24-3.01 (m, 2H, $\left.\mathrm{CH}_{2} \mathrm{CH}\left(\mathrm{NH}_{2}\right) \mathrm{CH}_{2}\right), 2.33-2.18\left(\mathrm{~m}, 1 \mathrm{H}, \mathrm{H} 2{ }^{\prime}\right), 2.06-1.93(\mathrm{~m}, 1 \mathrm{H}$, $\mathrm{H}_{2}$ ' '); MALDI-TOFMS $(\mathrm{m} / \mathrm{z}):[\mathrm{M}+\mathrm{H}]^{+}$calcd for $\mathrm{C}_{39} \mathrm{H}_{45} \mathrm{~N}_{8} \mathrm{O}_{13} \mathrm{P}_{2}$, 895.26; found, 895.65; $[\mathrm{M}+\mathrm{Na}]^{+}$calcd for $\mathrm{C}_{39} \mathrm{H}_{44} \mathrm{~N}_{8} \mathrm{NaO}_{13} \mathrm{P}_{2}$, 917.24; found, 917.51; $[\mathrm{M}+\mathrm{K}]^{+}$calcd for $\mathrm{C}_{39} \mathrm{H}_{44} \mathrm{KN}_{8} \mathrm{O}_{13} \mathrm{P}_{2}$, 933.21; found, 933.48; [M - H] $]^{-}$calcd for $\mathrm{C}_{39} \mathrm{H}_{43} \mathrm{~N}_{8} \mathrm{O}_{13} \mathrm{P}_{2}$, 893.24; found, 893.14.

\section{Conjugate 4}

Partly deprotected by TBAF treatment conjugate $\mathbf{2 5}$ was subjected to RPC as described for partly deprotected by TBAF conjugate 20 using gradient of EtOH in water $(0-75 \%)$. The Boc protective group was removed by formic acid as described for conjugate 2 . The residue was dissolved in $20 \%$ aqueous EtOH (10 mL per $0.05 \mathrm{~g}$ of fully protected derivative), and the solution was applied to a column with DEAE Sephadex A-25 in $20 \%$ aqueous EtOH. Elution was performed with a linear gradient of $\mathrm{NH}_{4} \mathrm{HCO}_{3}(0-1.0 \mathrm{M})$ in $20 \%$ aqueous EtOH. After drying, $0.125 \mathrm{~g}$ of conjugate $4(0.15 \mathrm{mmol}, 60 \%$ calcd to 9 taken into the coupling reaction) was obtained. $R_{\mathrm{f}}: 0.59(\mathrm{iPr} /$ $\left.\mathrm{H}_{2} \mathrm{O}, 4 / 1\right) ;{ }^{31} \mathrm{P}$ NMR $\left(\mathrm{D}_{2} \mathrm{O}\right) 0.75$ (s, 1P), -0.09 (s, 1P); ${ }^{1} \mathrm{H}$ NMR $\left(\mathrm{D}_{2} \mathrm{O}\right) 7.54$ (d, $J=7.8,2 \mathrm{H}, H$-Ar), 7.48-7.15 (m, 9H, $H-\operatorname{Ar}, H-\operatorname{Trp}), 7.06$ (s, $1 \mathrm{H}, H-\operatorname{Trp}), 7.00$ (t, $J=7.2,1 \mathrm{H}$, $H$-Trp), 6.83 (t, $J=7.2,1 \mathrm{H}, H-\operatorname{Trp}), 4.52-4.42$ (m, 1H, $\left.H 4^{\prime}\right)$, 4.01 (t, $\left.J=7.1,1 \mathrm{H}, \mathrm{CH}\left(\mathrm{NH}_{2}\right) \mathrm{CH}_{2}\right), 3.96-3.89$ (m, 1H, H3 '), 3.88-3.80 (m, 2H, H1'l'), 3.79-3.50 (m, 8H, OCH $\left.\mathrm{CH}_{2} \mathrm{OP}\right)$, 3.48-3.36 (m, 4H, NHCH $\left.\mathrm{CH}_{2} \mathrm{O}\right), 3.33-3.15(\mathrm{~m}, 5 \mathrm{H}$, $\left.\mathrm{NHCH}{ }_{2} \mathrm{CH}_{2} \mathrm{O}, \mathrm{CH}\left(\mathrm{NH}_{2}\right) \mathrm{CH}_{2}\right), 3.13-2.98$ (m, 2H, $\mathrm{H}^{\prime}$ ' 5 '”), 2.96-2.83 (m, 1H, CH( $\left.\left.\mathrm{NH}_{2}\right) \mathrm{CH}_{2}\right), 2.04-1.80$ (m, 2H, H2'2 '); MALDI-TOFMS $(m / z)$ : $[\mathrm{M}+\mathrm{H}]^{+}$calcd for $\mathrm{C}_{38} \mathrm{H}_{49} \mathrm{~N}_{4} \mathrm{O}_{14} \mathrm{P}_{2}$, 847.27; found, 847.46; [M $+\mathrm{Na}]^{+}$calcd for $\mathrm{C}_{38} \mathrm{H}_{48} \mathrm{~N}_{4} \mathrm{NaO}_{14} \mathrm{P}_{2}$, 869.25; found, 869.43; $[\mathrm{M}+\mathrm{K}]^{+}$calcd for $\mathrm{C}_{38} \mathrm{H}_{48} \mathrm{KN}_{4} \mathrm{O}_{14} \mathrm{P}_{2}$, 885.23; found, 885.42; $[\mathrm{M}-\mathrm{H}]^{-}$calcd for $\mathrm{C}_{38} \mathrm{H}_{47} \mathrm{~N}_{4} \mathrm{O}_{14} \mathrm{P}_{2}$, 845.26; found, 845.60; $[\mathrm{M}-2 \mathrm{H}+\mathrm{Na}]^{+}$calcd for $\mathrm{C}_{38} \mathrm{H}_{46} \mathrm{~N}_{4} \mathrm{NaO}_{14} \mathrm{P}_{2}$, 867.24; found, 867.50.

\section{Conjugate 5}

Partly deprotected by TBAF treatment conjugate $\mathbf{2 8}$ was subjected to RPC as described for partly deprotected by TBAF conjugate 20 using gradient of EtOH in water (0-65\%). The TFA protective group was removed by concentrated (25\%) aqueous ammonia for $3 \mathrm{~h}$. After evaporation, target product 5 was purified by anion exchange chromatography as described for conjugate 4. After drying, $0.09 \mathrm{~g}$ of conjugate 5 ( $0.125 \mathrm{mmol}, 50 \%$ calcd to 9 taken into the coupling reaction) was obtained. $R_{\mathrm{f}}: 0.67\left(\mathrm{iPr} / \mathrm{H}_{2} \mathrm{O}, 4 / 1\right) ;{ }^{31} \mathrm{P} \mathrm{NMR}\left(\mathrm{D}_{2} \mathrm{O}\right) 0.73(\mathrm{~s}$, $1 \mathrm{P}),-0.64$ (s, 1P); ${ }^{1} \mathrm{H}$ NMR $\left(\mathrm{D}_{2} \mathrm{O}\right) 7.65$ (d, $J=8.2,2 \mathrm{H}, H$-Ar), $7.62-7.52$ (m, 6H, H-Ar), 7.45 (d, $J=7.8,1 \mathrm{H}, H$-Trp), 7.43 (t, $J=7.9,2 \mathrm{H}, H$-Ar), 7.30 (d, $J=7.9,1 \mathrm{H}, H$-Trp), 7.13 (s, $1 \mathrm{H}$, $H$-Trp), 7.05 (t, $J=7.5,1 \mathrm{H}, H$-Trp), 6.97 (t, $J=7.5,1 \mathrm{H}$, $H$-Trp), 4.48-4.41 (m, 1H, H4'), 3.97-3.83 (m, 4H, H3', l'1',
$\left.\mathrm{CH}_{2} \mathrm{CH}\left(\mathrm{NH}_{2}\right) \mathrm{CH}_{2}\right), 3.83-3.71\left(\mathrm{~m}, 4 \mathrm{H}, \mathrm{OCH}_{2} \mathrm{CH}_{2} \mathrm{OP}\right)$, $3.70-3.56\left(\mathrm{~m}, 6 \mathrm{H}, \mathrm{CH}_{2} \mathrm{CH}\left(\mathrm{NH}_{2}\right) \mathrm{CH}_{2}, \mathrm{CH}_{2} \mathrm{CH}\left(\mathrm{NH}_{2}\right) \mathrm{CH}_{2}\right.$, $\left.\mathrm{NHCH}_{2} \mathrm{CH}_{2} \mathrm{O}\right), 3.55-3.43\left(\mathrm{~m}, 2 \mathrm{H}, \mathrm{CH}_{2} \mathrm{CH}\left(\mathrm{NH}_{2}\right) \mathrm{CH}_{2}\right)$, 3.03-2.95 (m, 2H, H5 '5'), 2.01-1.86 (m, 1H, H2'), 1.85-1.74 $\left(\mathrm{m}, 1 \mathrm{H}, \mathrm{H} 2\right.$ ' '); MALDI-TOFMS $(\mathrm{m} / \mathrm{z}):[\mathrm{M}+\mathrm{H}]^{+}$calcd for $\mathrm{C}_{34} \mathrm{H}_{41} \mathrm{~N}_{3} \mathrm{O}_{12} \mathrm{P}_{2}, 746.22$; found, 746.44; $[\mathrm{M}+\mathrm{Na}]^{+}$calcd for $\mathrm{C}_{34} \mathrm{H}_{41} \mathrm{~N}_{3} \mathrm{NaO}_{12} \mathrm{P}_{2}$, 768.21; found, 768.43; $[\mathrm{M}-\mathrm{H}]^{-}$calcd for $\mathrm{C}_{34} \mathrm{H}_{40} \mathrm{~N}_{3} \mathrm{O}_{12} \mathrm{P}_{2}, 744.21$; found, 744.41.

\section{Conjugate 6}

Partly deprotected by TBAF treatment conjugate 29 was dissolved in $20 \%$ aqueous EtOH $(10 \mathrm{~mL}$ per $0.05 \mathrm{~g}$ of the fully protected derivative), and the solution was applied to a column with DEAE Sephadex A-25 in 20\% aqueous EtOH. Elution was performed with a linear gradient of $\mathrm{NH}_{4} \mathrm{HCO}_{3}(0-0.5 \mathrm{M})$ in $20 \%$ aqueous $\mathrm{EtOH}$. The appropriate fractions were pooled and evaporated. Nucleobase deprotection and the subsequent purification by RPC were performed as described for conjugate $\mathbf{1}$. After drying, $0.06 \mathrm{~g}$ of conjugate $6(0.09 \mathrm{mmol}, 50 \%$ calcd to 15 taken into the coupling reaction) was obtained. $R_{\mathrm{f}}: 0.38$ (iPr/ $\left.\mathrm{H}_{2} \mathrm{O}, 4 / 1\right) ;{ }^{31} \mathrm{P}$ NMR $\left(\mathrm{D}_{2} \mathrm{O}\right) 0.85(\mathrm{~s}) ;{ }^{1} \mathrm{H}$ NMR $\left(\mathrm{D}_{2} \mathrm{O}\right) 7.78(\mathrm{~s}$, $1 \mathrm{H}, H 8$-Gua), 7.36 (d, $J=8.1,1 \mathrm{H}, H$-Trp), 7.27 (d, $J=8.1,1 \mathrm{H}$, $H$-Trp), 7.07 (s, 1H, $H$-Trp), 7.04 (t, $J=7.5,1 \mathrm{H}, H$-Trp), 6.94 (t, $J=7.5,1 \mathrm{H}, H-\operatorname{Trp}), 6.01\left(\mathrm{t}, J=6.8,1 \mathrm{H}, H 1^{\prime}\right), 4.61-4.55(\mathrm{~m}$, $\left.1 \mathrm{H}, H 4^{\prime}\right), 4.18-4.13\left(\mathrm{~m}, 1 \mathrm{H}, H 3^{\prime}\right), 4.10(\mathrm{t}, J=7.0,1 \mathrm{H}$, $\left.\mathrm{CH}\left(\mathrm{NH}_{2}\right) \mathrm{CH}_{2}\right), 4.05-3.94\left(\mathrm{~m}, 2 \mathrm{H}, \mathrm{CH}\left(\mathrm{NH}_{2}\right) \mathrm{CH}_{2}\right), 3.83-3.69$ (m, 2H, $\mathrm{H}_{5}$ ' 5 ' '), 3.44-3.23 (m, 4H, OCH $\mathrm{CH}_{2} \mathrm{OP}$ ), 3.22-3.04 $\left(\mathrm{m}, 4 \mathrm{H}, \mathrm{NHCH}_{2} \mathrm{CH}_{2} \mathrm{O}\right), 2.61-2.51\left(\mathrm{~m}, 1 \mathrm{H}, \mathrm{H} 2^{\prime}\right), 2.44-2.35$ $\left(\left(\mathrm{m}, 1 \mathrm{H}, \mathrm{H}^{\prime}\right.\right.$ ' '); MALDI-TOFMS $(\mathrm{m} / \mathrm{z}):[\mathrm{M}+\mathrm{H}]^{+}$calcd for $\mathrm{C}_{25} \mathrm{H}_{34} \mathrm{~N}_{8} \mathrm{O}_{9} \mathrm{P}, 621.22$; found, 621.26; $[\mathrm{M}+\mathrm{Na}]^{+}$calcd for $\mathrm{C}_{25} \mathrm{H}_{35} \mathrm{~N}_{8} \mathrm{NaO}_{9} \mathrm{P}$, 643.20; found, 643.24; [M $\left.+\mathrm{K}\right]^{+}$calcd for $\mathrm{C}_{25} \mathrm{H}_{34} \mathrm{KN}_{8} \mathrm{O}_{9} \mathrm{P}, 659.17$; found, 659.20.

\section{Conjugate 7}

Partly deprotected by TBAF treatment conjugate $\mathbf{3 1}$ was dissolved in minimal amount of $\mathrm{EtOH}$ and treated with concentrated $(25 \%)$ aqueous ammonia for $48 \mathrm{~h}$ under stirring at room temperature. After evaporation, the residue was dissolved in $40 \%$ aqueous $\mathrm{EtOH}$ ( $10 \mathrm{~mL}$ per $0.05 \mathrm{~g}$ of fully protected derivative), and subjected to anion exchange chromatography as described for conjugate 1. The appropriate fractions were pooled and evaporated. The residue was treated with $80 \%$ aqueous acetic acid $(5 \mathrm{~mL}$ per $0.1 \mathrm{~g}$ of the fully protected derivative) for $30 \mathrm{~min}$, diluted tenfold with water and chilled. The solution was neutralized by addition of concentrated (25\%) aqueous ammonia. Target conjugate 7 was purified by RPC as described for conjugate 1 . After drying, $0.015 \mathrm{~g}$ of conjugate 7 ( $0.035 \mathrm{mmol}, 25 \%$ calcd to $\mathbf{3 0}$ taken into the coupling reaction) was obtained. $R_{\mathrm{f}}: 0.1(\mathrm{EtOH}) ;{ }^{31} \mathrm{P}$ NMR $\left(\mathrm{D}_{2} \mathrm{O}\right) 0.75(\mathrm{~s})$; ${ }^{1} \mathrm{H}$ NMR $\left(\mathrm{D}_{2} \mathrm{O}\right) 8.04(\mathrm{~s}, 1 \mathrm{H}, H 8-\mathrm{Gua}), 6.29(\mathrm{t}, J=6.7,1 \mathrm{H}$, $\left.H 1^{\prime}\right), 4.73-4.68\left(\mathrm{~m}, 1 \mathrm{H}, H 4^{\prime}\right), 4.24-4.18\left(\mathrm{~m}, 1 \mathrm{H}, H 3{ }^{\prime}\right), 4.01(\mathrm{t}$, 
$\left.J=4.5,2 \mathrm{H}, \mathrm{OCH}_{2} \mathrm{CH}_{2} \mathrm{OP}\right), 3.84-3.78$ (m, 2H, $\mathrm{H}^{\prime}{ }^{5}$ ' '), 3.67 (t, $\left.J=4.5,2 \mathrm{H}, \mathrm{OCH}_{2} \mathrm{CH}_{2} \mathrm{OP}\right), 3.60-3.46\left(\mathrm{~m}, 2 \mathrm{H}, \mathrm{NHCH}_{2} \mathrm{CH}_{2} \mathrm{O}\right)$, 3.19-3.11 (m, 2H, $\left.\mathrm{NHCH}_{2} \mathrm{CH}_{2} \mathrm{O}\right), 2.88-2.77$ (m, $1 \mathrm{H}, \mathrm{H}_{2}$ '), 2.60-2.49 (m, 1H, H2' '); MALDI-TOFMS $(\mathrm{m} / \mathrm{z}):[\mathrm{M}+\mathrm{H}]^{+}$ calcd for $\mathrm{C}_{14} \mathrm{H}_{24} \mathrm{~N}_{6} \mathrm{O}_{8} \mathrm{P}, 435.14$; found, 434.99; $[\mathrm{M}+\mathrm{Na}]^{+}$ calcd for $\mathrm{C}_{14} \mathrm{H}_{23} \mathrm{~N}_{6} \mathrm{NaO}_{8} \mathrm{P}$, 457.12; found, 457.00

\section{Conjugate 8}

Partly deprotected by TBAF treatment conjugate $\mathbf{3 3}$ was subjected to anion exchange chromatography as described for conjugate 1 . The appropriate fractions were pooled and evaporated. The TFA and Ac protective groups were removed by concentrated (25\%) aqueous ammonia treatment for $3 \mathrm{~h}$. After evaporation, target product 8 was purified by RPC as described for conjugate 1. After drying, $0.026 \mathrm{~g}(0.055 \mathrm{mmol}, 37 \%$ calcd to 32 taken into the coupling reaction) was obtained. $R_{\mathrm{f}}: 0.32$ $($ EtOH $) ;{ }^{31} \mathrm{P}$ NMR $\left(\mathrm{D}_{2} \mathrm{O}\right): 0.85(\mathrm{~s}) ;{ }^{1} \mathrm{H}$ NMR $\left(\mathrm{D}_{2} \mathrm{O}\right) 7.62$ (d, $J=8.0,1 \mathrm{H}, H$-Trp), 7.52 (d, $J=8 ., 1 \mathrm{H}, H$-Trp), 7.31 (s, $1 \mathrm{H}$, $H$-Trp), $7.26(\mathrm{t}, J=7.5,1 \mathrm{H}, H$-Trp), 7.17 (t, $J=7.5,1 \mathrm{H}$, $H$-Trp), 4.30-4.24 (m, 1H, H4'), 4.20 (dd, $J=8.0,6.2,1 \mathrm{H}$, $\left.\mathrm{CH}\left(\mathrm{NH}_{2}\right) \mathrm{CH}_{2}\right), 4.02-3.74\left(\mathrm{~m}, 6 \mathrm{H}, \mathrm{Hl} \mathrm{l}^{\prime}\right.$ ', $\left.\mathrm{OCH}_{2} \mathrm{CH}_{2} \mathrm{OP}\right)$, 3.65-3.05 (m, 9H, H3', $\mathrm{H}_{5}$ ' 5 ', $\left., \mathrm{NHCH}_{2} \mathrm{CH}_{2} \mathrm{O}, \mathrm{CH}\left(\mathrm{NH}_{2}\right) \mathrm{CH}_{2}\right)$, 2.17-2.03 (m, 1H, H2'), 1.93-1.82 (m, 1H, H2'); MALDI-TOFMS $(m / z):[\mathrm{M}+\mathrm{H}]^{+}$calcd for $\mathrm{C}_{20} \mathrm{H}_{30} \mathrm{~N}_{2} \mathrm{O}_{9} \mathrm{P}$, 472.18; found, 472.02; $[\mathrm{M}+\mathrm{Na}]^{+}$calcd for $\mathrm{C}_{20} \mathrm{H}_{29} \mathrm{~N}_{2} \mathrm{NaO}_{9} \mathrm{P}$, 494.17; found, 494.02 .

\section{Supporting Information}

The synthesis and physicochemical characteristics for compounds $9,10,12,15,30$, and 32 , the synthetic scheme and physicochemical characteristics for intermediates in the synthesis of compound $\mathbf{1 7}$ and the physicochemical characteristics for compounds 11, 13, 16, 19, 23, 24, 26, and $\mathbf{2 7}$ are provided in the Supporting Information.

\section{Supporting Information File 1}

Syntheses and characteristics for selected compounds. [http://www.beilstein-journals.org/bjoc/content/ supplementary/1860-5397-9-326-S1.pdf]

\section{Acknowledgements}

This work was supported by the President program "Leading Scientific Schools" (project nos. NS-64.2012.4 and 2429.2012.3), the Interdisciplinary Integration project no. 60 of the Presidium of Siberian Branch of Russian Academy of Sciences, and the grant of the Russian Foundation for Basic Research (project nos. 12_04_01454_a and 13-03-00437_a). We also acknowledge support from the Ministry of Education and Science of the Russian Federation "Measures to Attract
Leading Scientists to Russian Educational Institutes" (Grant no. 11.G34.31.0045).

\section{References}

1. Zheng, R.; Shi, Y.; Jia, Z.; Zhao, C.; Zhang, Q.; Tan, X. Chem. Soc. Rev. 2010, 39, 2827-2834. doi:10.1039/b924875g

2. Yurkovskaya, A.; Morozova, O.; Gescheidt, G. Structures and reactivity of radicals followed by magnetic resonance. In Encyclopedia of Radicals in Chemistry, Biology and Materials; Chatgilialoglu, C.; Studer, A., Eds.; Wiley and Sons: Chichester, U.K., 2012; Vol. 1 , pp 175-206. doi:10.1002/9781119953678.rad008

3. Hore, P. J.; Broadhurst, R. W. Prog. Nucl. Magn. Reson. Spectrosc. 1993, 25, 345-402. doi:10.1016/0079-6565(93)80002-B

4. Day, I. J.; Maeda, K.; Paisley, H. J.; Mok, K. H.; Hore, P. J. J. Biomol. NMR 2009, 44, 77-86. doi:10.1007/s10858-009-9322-2

5. Janssen, G. J.; Daviso, E.; van Son, M.; de Groot, H. J. M.; Alia, A.; Matysik, J. Photosynth. Res. 2010, 104, 275-282. doi:10.1007/s11120-009-9508-1

6. Morozova, O. B.; Yurkovskaya, A. V. Angew. Chem., Int. Ed. 2010, 49, 7996-7999. doi:10.1002/anie.201003780

7. Morozova, O. B.; Kaptein, R.; Sagdeev, R. Z.; Yurkovskaya, A. V. Appl. Magn. Reson. 2013, 44, 233-245. doi:10.1007/s00723-012-0403-0

8. Venkatesan, N.; Kim, B. H. Chem. Rev. 2006, 106, 3712-3761. doi:10.1021/cr0502448

9. Morozova, O. B.; Kiryutin, A. S.; Sagdeev, R. Z.; Yurkovskaya, A. V. J. Phys. Chem. B 2007, 111, 7439-7448. doi:10.1021/jp067722i

10. Morozova, O. B.; Kaptein, R.; Yurkovskaya, A. V. J. Phys. Chem. B 2012, 116, 12221-12226. doi:10.1021/jp307956q

11. Morozova, O. B.; Kaptein, R.; Yurkovskaya, A. V. J. Phys. Chem. B 2012, 116, 8058-8063. doi:10.1021/jp301760b

12. Steenken, S.; Jovanovic, S. V. J. Am. Chem. Soc. 1997, 119, 617-618. doi:10.1021/ja962255b

13. Yurkovskaya, A. V.; Snytnikova, O. A.; Morozova, O. B.; Tsentalovich, Y. P.; Sagdeev, R. Z. Phys. Chem. Chem. Phys. 2003, 5, 3653-3659. doi:10.1039/b305783f

14. Morozova, O. B.; Kiryutin, A. S.; Yurkovskaya, A. V. J. Phys. Chem. B 2008, 112, 2747-2754. doi:10.1021/jp0752318

15. Morozova, O. B.; Korchak, S. E.; Sagdeev, R. Z.; Yurkovskaya, A. V. J. Phys. Chem. A 2005, 109, 10459-10466. doi:10.1021/jp054002n

16. Morozova, O. B.; Yurkovskaya, A. V. J. Phys. Chem. B 2008, 112, 12859-12862. doi:10.1021/jp807149a

17. Nguyen, T. X.; Kattnig, D.; Mansha, A.; Grampp, G.; Yurkovskaya, A. V.; Lukzen, N. J. Phys. Chem. A 2012, 116, 10668-10675. doi:10.1021/jp307122h

18. Saprygina, N. N.; Morozova, O. B.; Kaptein, R.; Yurkovskaya, A. V.; Sagdeev, R. Z. Dokl. Phys. Chem. 2013, 449, 66-70. doi:10.1134/S0012501613040027

19. Morozova, O. B.; Hore, P. J.; Sagdeev, R. Z.; Yurkovskaya, A. V. J. Phys. Chem. B 2005, 109, 21971-21978. doi:10.1021/jp053394v

20. Morozova, O. B.; Saprygina, N. N.; Fedorova, O. S.; Yurkovskaya, A. V. Appl. Magn. Reson. 2011, 41, 239-250. doi:10.1007/s00723-011-0252-2

21. Garipova, I. Yu.; Silnikov, V. N. Russ. Chem. Bull. 2002, 51, 1940-1944. doi:10.1023/A:1021329324527

22. Abramova, T. V. Molecules 2013, 18, 1063-1075. doi:10.3390/molecules18011063 
23. De Koning, M. C.; Ghisaidoobe, A. B. T.; Duynstee, H. I.;

Ten Kortenaar, P. B. W.; Filippov, D. V.; van der Marel, G. A.

Org. Process Res. Dev. 2006, 10, 1238-1245. doi:10.1021/op060133q

24. Ghisaidoobe, A. B. T.; de Koning, M. C.; Duynstee, H. I.;

Ten Kortenaar, P. B. W.; Overkleeft, H. S.; Filippov, D. V.;

van der Marel, G. A. Tetrahedron Lett. 2008, 49, 3129-3132.

doi:10.1016/j.tetlet.2008.03.025

25. van der Heden van Noort, G. J.; Schein, C. H.; Overkleeft, H. S.; van der Marel, G. A.; Filippov, D. V. J. Pept. Sci. 2013, 19, 333-336. doi:10.1002/psc.2508

26. Arunachalam, T. S.; Wichert, C.; Appel, B.; Müller, S. Org. Biomol. Chem. 2012, 10, 4641-4650. doi:10.1039/c2ob25328c

27. Abramova, T. V. Methodology of obtaining modified oligodeoxyrobonucleotides for of creation effective tools for molecular biology investigations. Dr.Sc. Thesis, Institute of Chemical Biology and Fundamental Medicine, SB RAS, Novosibirsk, Russia, 2012.

28. Abramova, T. V.; Vasileva, S. V.; Koroleva, L. S.; Kasatkina, N. S.; Silnikov, V. N. Bioorg. Med. Chem. 2008, 16, 9127-9132. doi:10.1016/j.bmc.2008.09.029

29. Bodanszky, M.; Bednarek, M. A. J. Protein Chem. 1989, 8, 461-469. doi:10.1007/BF01026430

30. Sinha, N. D.; Striepeke, S. Oligonucleotides with reporter groups attached to the 5'-terminus. In Oligonucleotides and Analogues: $A$ Practical Approach; Eckstein, F., Ed.; Oxford University Press: New York, NY, USA, 1991; pp 185-210.

31. Itakura, K.; Bahl, P.; Katagiri, N.; Michniewicrz, J. J.; Wightman, H.; Narang, S. A. Can. J. Chem. 1973, 51, 3649-3651. doi:10.1139/v73-543

32. Eritja, R.; Walker, P. A.; Randall, S. K.; Goodman, M. F.; Kaplan, B. E. Nucleosides Nucleotides 1987, 6, 803-814. doi:10.1080/15257778708073426

33. Curphey, T. J. J. Org. Chem. 1979, 44, 2805-2807. doi:10.1021/jo01329a049

34. Mazzei, M.; Balbi, A.; Grandi, T.; Sottofattori, E.; Garzoglio, R.; Abramova, T.; Ivanova, E. Farmaco 1993, 48, 1649-1661.

35. van Boom, J. H.; Burgers, P. M. J. Tetrahedron Lett. 1976, 17 , 4875-4878. doi:10.1016/S0040-4039(00)78935-0

\section{License and Terms}

This is an Open Access article under the terms of the Creative Commons Attribution License

(http://creativecommons.org/licenses/by/2.0), which permits unrestricted use, distribution, and reproduction in any medium, provided the original work is properly cited.

The license is subject to the Beilstein Journal of Organic Chemistry terms and conditions:

(http://www.beilstein-journals.org/bjoc)

The definitive version of this article is the electronic one which can be found at: doi:10.3762/bjoc. 9.326 